\title{
Evaluation of pharmacy-based HIV testing in a high-risk New York City community
}

\author{
S Amesty*, N Crawford, V Nandi, A Rivera, C Fuller \\ From International Symposium HIV and Emerging Infectious Diseases 2014 \\ Marseille, France. 21-23 May 2013
}

\begin{abstract}
Introduction
Injection drug users (IDUs) face limited access to HIV testing and experience delayed HIV diagnoses. New York City (NYC) pharmacies play an important role in HIV prevention among IDUs through the Expanded Syringe Access Program (ESAP), which provides access to sterile syringes without a prescription. We examined in-pharmacy HIV testing among syringe/non-syringe customers in ESAP pharmacies in NYC.
\end{abstract}

\section{Materials and methods}

Syringe/non-syringe pharmacy customers were recruited in two ESAP community pharmacies in high HIV prevalence neighborhoods to complete a 30-minute survey. In-pharmacy HIV testing was offered to all HIV-negative participants. Descriptive statistics, chi-square and Fisher's exact tests were performed for categorical outcomes and t-tests for continuous outcomes to determine significant differences in individual characteristics between patrons who accepted in-pharmacy HIV testing compared with those who declined. Stepwise multivariable logistic regression was used to assess the relationship between receiving in-pharmacy HIV testing and customer characteristics identified from bivariate analyses.

\section{Results}

Of 327 participants, most were male (57\%), black (80\%), had ever used hard drugs (88\%); 217 (66.4\%) were HIVnegative, and $39.6 \%$ received in-pharmacy HIV testing. After adjustment, being female (AOR 2.71; 95\% CI 1.44-5.10), having multiple sex partners (AOR 1.31; $95 \%$ CI 1.08-1.59), having an HIV test more than 12 months ago (AOR 2.90; 95\% CI 1.30-6.47), injecting drugs (AOR 2.26; 95\% CI 1.04-4.91), and seeing the same regular

\footnotetext{
Columbia University, New York, USA
}

(c) 2014 Amesty et al; licensee BioMed Central Ltd. This is an Open Access article distributed under the terms of the Creative Commons Attribution License (http://creativecommons.org/licenses/by/4.0), which permits unrestricted use, distribution, and reproduction in any medium, provided the original work is properly cited. The Creative Commons Public Domain Dedication waiver (http:// creativecommons.org/publicdomain/zero/1.0/) applies to the data made available in this article, unless otherwise stated. medical provider (AOR 0.33; 95\% CI 0.17-0.67) were associated with receiving in-pharmacy HIV test.

\section{Conclusions}

This study presents evidence for a potential new venue for HIV testing that could provide access for hard-toreach populations that have limited access to HIV testing. The approach we used was feasible to pharmacists. Given that pharmacies are located everywhere in NYC and have access to new point-of-care and home-based HIV testing technologies, the provision of HIV testing in pharmacies could provide easy access to HIV testing for IDUs as well as other populations.

Published: 23 May 2014

doi:10.1186/1471-2334-14-S2-P4

Cite this article as: Amesty et al:: Evaluation of pharmacy-based HIV testing in a high-risk New York City community. BMC Infectious Diseases 2014 14(Suppl 2):P4.
Submit your next manuscript to BioMed Central and take full advantage of:

- Convenient online submission

- Thorough peer review

- No space constraints or color figure charges

- Immediate publication on acceptance

- Inclusion in PubMed, CAS, Scopus and Google Scholar

- Research which is freely available for redistribution Submit your manuscript at C BioMed Central

\section{BiolMed Central}

